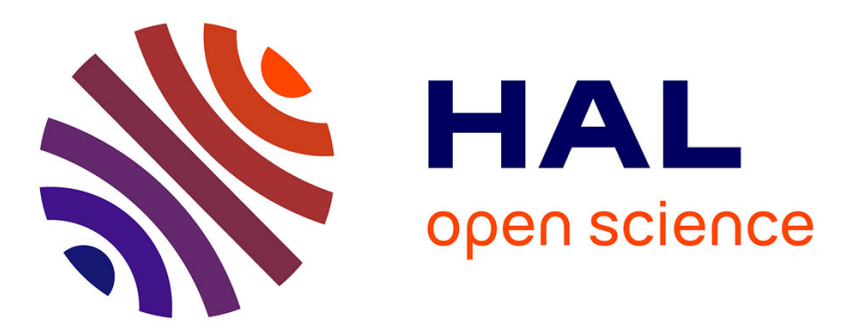

\title{
Somatostatin, cortistatin and their receptors in tumours
}

Marco Volante, R. Rosas, E. Allìa, R. Granata, A. Baragli, G. Muccioli, Mauro Papotti

\section{To cite this version:}

Marco Volante, R. Rosas, E. Allìa, R. Granata, A. Baragli, et al.. Somatostatin, cortistatin and their receptors in tumours. Molecular and Cellular Endocrinology, 2008, 286 (1-2), pp.219. 10.1016/j.mce.2007.12.002 . hal-00531971

\section{HAL Id: hal-00531971 \\ https://hal.science/hal-00531971}

Submitted on 4 Nov 2010

HAL is a multi-disciplinary open access archive for the deposit and dissemination of scientific research documents, whether they are published or not. The documents may come from teaching and research institutions in France or abroad, or from public or private research centers.
L'archive ouverte pluridisciplinaire HAL, est destinée au dépôt et à la diffusion de documents scientifiques de niveau recherche, publiés ou non, émanant des établissements d'enseignement et de recherche français ou étrangers, des laboratoires publics ou privés. 


\section{Accepted Manuscript}

Title: Somatostatin, cortistatin and their receptors in tumours

Authors: M. Volante, R. Rosas, E. Allìa, R. Granata, A.

Baragli, G. Muccioli, M. Papotti

PII: $\quad$ S0303-7207(07)00451-0

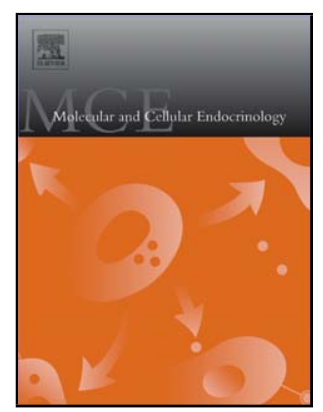

DOI: doi:10.1016/j.mce.2007.12.002

Reference: MCE 6765

To appear in: Molecular and Cellular Endocrinology

Received date: $\quad 30-4-2007$

Revised date: $\quad 30-7-2007$

Accepted date: $\quad 1-12-2007$

Please cite this article as: Volante, M., Rosas, R., Allìa, E., Granata, R., Baragli, A., Muccioli, G., Papotti, M., Somatostatin, cortistatin and their receptors in tumours, Molecular and Cellular Endocrinology (2007), doi:10.1016/j.mce.2007.12.002

This is a PDF file of an unedited manuscript that has been accepted for publication. As a service to our customers we are providing this early version of the manuscript. The manuscript will undergo copyediting, typesetting, and review of the resulting proof before it is published in its final form. Please note that during the production process errors may be discovered which could affect the content, and all legal disclaimers that apply to the journal pertain. 


\title{
SOMATOSTATIN, CORTISTATIN AND THEIR RECEPTORS IN TUMOURS
}

M. Volante, R. Rosas, E. Allìa^, R. Granata§, A. Baragli*, G. Muccioli* and M. Papotti

Department of Clinical \& Biological Sciences, University of Turin at San Luigi Hospital, Orbassano, and Divisions of ^Pathology, §Endocrinology and *Pharmacology,

University of Turin, Torino, Italy

Work partially supported by grants from the Italian Ministry of Research, Rome (PRIN 2006 to MP).

Address for correspondence:

Mauro Papotti, Anatomia Patologica, Università di Torino

Ospedale San Luigi, Regione Gonzole 10

10043 Orbassano, Torino, Italy

Phone and fax +390116705432; e-mail: mauro.papotti@unito.it

\begin{abstract}
Somatostatin (SS) and its synthetic analogs have a role in the treatment of neuroendocrine tumours both in terms of symptoms control and antiproliferative activities. These effects are mediated by five SS receptors, widely expressed in both human neuroendocrine and nonneuroendocrine tumours, which were demonstrated to be diagnostically and therapeutically valuable targets . Cortistatin (CST), a brain cortex peptide, partially homologous to SS and having similar functions is also expressed in peripheral tissues and tumours. CST binds all SS receptors, and, differently from SS, also the ghrelin receptor GHSR1a and the CST specific receptor MrgX2. The expression profile of CST is mostly restricted to neuroendocrine tumours (gastrointestinal, pancreas, lung, parathyroid, thyroid, adrenal). In these tumours, CST probably acts via the SS or ghrelin receptor, the MrgX2 receptor being absent. Thus, in comparison to SS analogs, CST synthetic analogs may represent additional diagnostic/therapeutic tools in those tumors expressing the receptors for SS, for ghrelin or for both peptides.
\end{abstract}

KEY WORDS: somatostatin, cortistatin, somatostatin receptor, $\mathrm{MrgX} 2$ receptor, human cancer, neuroendocrine 


\section{INTRODUCTION}

Somatostatin (SS) and cortistatin (CST) are two hormones sharing marked amino acidic sequence homology, as a result of a probable primordial gene duplication that finally lead to the occurrence of similar preprosomatostatin and preprocortistatin genes in chromosomes 3 and 1, respectively. Beside this duplication, other related genes may exist, including a mouse gastrointestinal peptide named thrittene, which has a 13/28 amino acid homology with somatostatin. SS and CST exert partially similar central and peripheral functions. Hypothalamic SS classically suppresses growth hormone (GH) and TSH release; insulin and other intestinal peptides are inhibited as well. Several other peripheral activities are known, for CST and SS, which act as neurotransmitters, neuromodulators, regulators of inflammation and immune function and finally, as regulators of (tumour) cell proliferation. Central activities of CST only partially overlap with those of SS, while CST and SS seem to share the same endocrine activities in humans (Bloom et al 1974, Epelbaum et al 1986, DeLecea et al 1996, Gottero et al 2004, DeLecea \& Castano 2006). The CST role in peripheral tissues and organs is less well understood, and only an effect on immune system and on tumour cell growth has been demonstrated so far (Cassoni et al 2002, Dalm et al 2004, DeLecea \& Castano 2006, Ferone et al 2006).

The above listed functions of SS and CST are mediated by a family of receptors that recognize these ligands with different affinity (see review in Patel 1997 and 1999). Originally, five different somatostatin receptor types (sst1-5) were identified and cloned and found able to bind not only native SS forms (SS-14 and SS-28), but also their synthetic analogs, such as octreotide, lanreotide and pasireotide (SOM230). Subsequently, CST was also shown able to bind all SS types, although not all emerging activities of CST could be explained by its binding to sst. In fact, other binding sites for CST were identified, including the ghrelin receptor on the one side (GHSR1a) and an apparent CST specific receptor on the other (MrgX-2). The latter was found capable of binding adrenomedullin as well (Kamohara et al 2005). From this complex scenario [Table 1], it is evident that different hormones exert different functions, sharing or competing for different receptors in normal and altered central or peripheral tissues. While the role of SS in neoplastic conditions has been extensively studied, establishing the usefulness of SS analogs in the control of hormonal secretion and neoplastic growth in several neuroendocrine tumours, less clear remains the role of CST in the same tumours, as well as that of SS in non-endocrine tumours.

This review will highlight selected evidence of the expression of SS and CST family of ligands and receptors indifferent human tumour types, and of the antiproliferative effects of both their natural and synthetic analogs.

\section{THE LIGANDS}




\section{Somatostatin expression in tumours}

Somatostatin (SS) is an acidic polypeptide, which is widely distributed throughout the central nervous system,different peripheral tissues and organs. It is mainly produced by delta cells of the gastrointestinal tract and by pancreatic islets, but it is also present in the nervous plexuses of the intestinal wall. Tumours related to the aforementioned cells were shown to produce and secrete SS. SS-14 and SS-28 are the two biologically active forms of SS. Since the original description by Krulich and coworkers (1968) of a factor present in hypothalamic extracts able to inhibit GH secretion from the anterior pituitary cultured cells, several biological functions have been described for SS. These include a potent inhibition of basal and stimulated secretion from a wide variety of endocrine and exocrine cells, as well as neuromodulatory actions in the central nervous system, with effects on locomotory activity and cognitive functions (Epelbaum et al 1986, Weir et al 1985, Bloom et al 1974 and 1975, Raynor et al 1993a). SS also possesses antiproliferative properties and may be an important hormonal regulator of cell proliferation and differentiation (Lamberts et al 1991).

Somatostatin-producing tumours (somatostatinomas) are rare functioning pancreatic neuroendocrine tumours (less than $2 \%$ of all abdominal endocrine tumours), having delta-cell morphology, high SS production and correlated clinical symptoms (so called "somatostatinoma syndrome", characterized by steatorrhea, cholelithiasis, hyperglycemia and weight loss). Similar tumours occur also in the duodenum (Soga et al 1999, Hami et al 2001) and, more rarely, in the lung and paraganglia (DeLellis et al 2004). These latter are generally unable to produce a clinical syndrome, despite immunoreactive SS being present in a cospicuous fraction of tumour cells (Dayal et al 2004). A fraction of SS producing tumours is associated to familial syndromes including neurofibromatosis, von-Hipple-Lindau and multiple endocrine neoplasia type I (MEN1). Approximately half of cases are malignant and liver metastases are commonly observed (Moayedoddin et al 2006). The above tumours have the organoid or trabecular histological structure typical of all neuroendocrine tumours and intensely express SS in the tumour cell cytoplasm. Other hormonal products, including cortistatin, can be co-expressed in a small percentage of tumour cells (Dayal et al 2004, Low 2004) [Figure 1a-b].

Duodenal somatostatin-producing tumours generally contain characteristic psammoma bodies, composed of calcium crystals. Amyloid deposition is an additional possible feature of these tumours. Other human tumours may occasionally produce SS, including medullary thyroid carcinoma (Mato et al 1998), endocrine pancreatic tumours with multihormonal activity (eg insulinomas or glucagonomas) (DeLellis et al 2004), neuroblastoma and ganglioneuroma (Kogner et al 1997), adreno-cortical tumours (Uberberg et al 2005). Finally non neuroendocrine tumours 
such as breast, prostate, colorectal (Mao et al 2005), pancreatic (Tamiolakis et al 2005) adenocarcinomas, mixed ductal-endocrine carcinomas of the pancreas (Ohike et al 2003) and schwannoma (Mawrin et al 2005), may contain scattered SS-producing cells. The significance of this finding is not clear and the limited expression of SS in such tumour does not usually bear any clinical impact.

\section{Cortistatin Expression in tumours}

Cortistatin (CST) is a neuropeptide recently discovered in rat, mouse and human brain cortex, mapping to chromosome $1 \mathrm{p}$ and exhibiting a strong structural homology to somatostatin (Spier\&DeLecea 2000, De Lecea et al 1996, Fukusumi et al 1997, De Lecea et al 1997). CST was readily traced in peripheral tissues, including the endocrine pancreas (Papotti et al 2003, Dalm et al 2004). Two mature products, CST-17 and CST-29 (or CST-14 in the mouse) exist, both able to bind all five sst (subtypes 1-5) with an affinity comparable to that of SS14 (Siehler et al 1998, Spier et al 2005). Ssts mediate multiple activities including neurotransmission, neuromodulation, regulation of endocrine and exocrine secretions and also the inhibition of tumour growth (Kreienkamp et al 1999; Reichlin et al 1998). These effects may be equally mediated by SS or CST. However, the existence of CST biological activities not shared by SS (DeLecea\&Castano 2006), led to postulate the existence of a specific CST receptor, subsequently identified as the MrgX2 receptor (Spier \&DeLecea 2000, Robas et al 2003). In addition, as opposed to SS, both CST-14 and CST-17 bind the ghrelin receptor type 1a (GHS-R1a) (Deghenghi et al 2001; Deghenghi et al 2003; Broglio et al 2002).

In humans, CST mRNA (and also protein, although with a generally focal reactivity) was detected in all pheochromocytomas, parathyroid adenomas and neuroendocrine tumours of the lung, as well as in non-functioning pancreatic endocrine tumours and in the majority of the other neuroendocrine tumours tested, namely neuroendocrine tumours of the gastrointestinal tract, functioning neuroendocrine tumours of the pancreas, medullary thyroid carcinomas, parathyroid carcinomas and Merkel cell carcinomas (Allia et al 2005) [Figure 2]. In the non-neuroendocrine tumour group, a weak mRNA signal (but no immunoreactivity) was present in spare cases of adenocarcinomas of the lung, stomach, colon, and in the thyroid gland follicular tumours (Allia et al 2005).

The presence of CST peptide (but not of SS) in parathyroid chief cells and related tumours was a peculiar and unexpected finding. Besides parathormone, parathyroid cells may occasionally produce other hormones, including calcitonin (Weber et al 1991). In the absence of demonstrable specific CST receptors, the local paracrine effects of CST in the parathyroids are likely mediated by 
the ssts expressed in these glands (particularly subtype 2). With regard to gastroenteropancreatic neuroendocrine tumours, scattered CST immunoreactive cells (but not the corresponding MrgX2 receptor) were found in most cases, although no preferential association of CST with the tumour behaviour or specific hormone secretion was found [Figure 1c]. Concerning putative endocrine precursor lesions, the neuroendocrine cell hyperplasia of the gastric mucosa revealed to be CST immunoreactive. Despite the existence of CST-secreting neuroendocrine tumours can be postulated, a clinical syndrome sustained by CST overexpression has not been described yet. As for parathyroid tumour cells, since all such tumours did not contain the specific CST receptor, CST action is assumed to be mediated again by ssts and/or by ghrelin receptor (GHSR-1a) that had previously been detected in gastroenteropancreatic neuroendocrine tumours (Papotti et al 2001c, Volante et al 2002).

Of particular interest appears CST expression in those immune cells where no SS is expressed, for example in monocytes-macrophages, lymphocytes and thymocytes (Dalm et al 2003a and 2003b). Increasing evidence suggests that CST binds with high affinity the sst2 expressed on immune cells (Dalm et al 2003b), providing the basis for an autocrine stimulation: it is in fact believed that CST favours the induction of monocytes and thymocytes differentiation through the inhibition of their proliferation (Dalm et al 2003a; Dalm et al 2004).

\section{THE RECEPTORS}

\section{Somatostatin receptors}

The somatostatin receptors (sst) family comprises membrane bound receptors, the first identified in 1978 by Schonbrunn and Tashjian (1978) in rat pituitary cells. Subsequently, several studies postulated the existence of multiple receptor subtypes with different affinities for SS-14 and SS-28, and for the group of synthetic agonists (Raynor \& Reisine 1992). Five different sst genes have been identified and characterized from 1992 to 1994, and named sst1 through sst5 (Hoyer et al 1995). Their genes localize in five different chromosomes (Patel 1997) and the protens display a remarkable degree of structural conservation across species (Reisine \& Bell 1995, Patel et al 1995). Ssts belong to the family of $\mathrm{G}$ protein-coupled receptors, tipically consisting of extracellular domains forming the ligand binding site, a single polypeptide chain with seven transmembrane domains and intracellular domains mediating signal transduction.

Each sst subtype mediates different biological actions of SS, via the activation of different intracellular systems such as inhibition of adenylate cyclase (with decrease of intracellular cyclic AMP levels), reduction of intracellular calcium levels, and stimulation of phosphotyrosine phosphatase or MAP kinase activity (Patel 1997, Reisine \& Bell 1995). The inhibitory effects on 
adenylate cyclase activity and calcium influx result in the inhibition of hormonal secretion. Most relevant,the tyrosine phosphatase-mediated activation of sst1 and sst2 has been related to the antimitotic activity of somatostatin analogs, while the activation of sst5, via reduction of intracellular calcium levels, also results in the inhibition of cell proliferation. Moreover, sst3 selectively induces apoptosis (Bousquet et al 2001, Hu et al, 2004).

The intracellular routing of ssts following ligand activation is similar to other $G$ proteincoupled receptors and includes receptor phosphorylation and internalization (Hukovic et al, 1996, Liu et al 2005, Cescato et al 2006). Internalized ssts into endosomes are dephosphorylated and subsequently recycled back to the plasma membrane or degraded. Down-regulation of the receptors can be related to lysosome degradation of internalized receptors and/or decreased synthesis of ssts mRNA and protein. All sst subtypes may form functionally active homo- or heterodimers: sst5 forms heterodimers with sst1 (Rocheville et al, 2000) and sst2A with sst3, which results in sst3 functional inactivation (Pfeiffer et al 2001). The presence of functionally active homo- and/or heterodimers of sst is key to partially explain the different intracellular signaling pathways activated by the sst subtypes in individual SS-target cells. Those cells which express more than one receptor subtype may harbor both homo- and hetero-dimer formation; their peculiar pharmacological and functional profiles, in most instances, result in altered intracellular routing and agonist-induced desensitization. As an example, sst2A-sst3 heterodimers desensitized at a slower rate than sst2A and sst3 homodimers or monomers, following prolonged SS exposure (Pfeiffer et al 2001). Whether CST may interfere with sst heterodimer formation, modulating pharmacological and functional properties, remains to be established.

The expression and tissue distribution of ssts have been extensively studied and a detailed reviews on the subject have been published (Patel et al 1995, Reubi et al 1997, Reubi 2004, Volante et al 2004, Reubi et al 2005). The interest in these receptors keeps growing due to the expanding therapeutic opportunities opened up by the use of synthetic SS analogs for the control of hormonal symptoms and cell growth of neuroendocrine tumours of various locations (Hofland et al 2005, Kaltsas et al 2005, Fedele et al 2007, Zatelli et al 2007).

\section{Expression and localization of SS receptors in neuroendocrine tumours}

High level of ssts expression are generally detected in neuroendocrine tumours, including pituitary adenomas, endocrine pancreatic tumours, gastrointestinal and lung carcinoids, paragangliomas, pheochromocytomas, small cell carcinomas, Merkel cell carcinomas, neuroblastomas and medullary thyroid carcinomas (Reubi et al 1992a, Reubi et al 1992b, Reubi et al 1994a, Reubi et al 1996, Papotti et al 2000, Papotti et al 2001a, Papotti et al 2001b, Papotti et al 2002, Sestini et al 1996, Uberberg et al 2005, Taboada et al 2007). ssts expression in all these 
tumours has been largely studied by means of various techniques, including binding (even in vivo scintigraphic) assays, immunohistochemistry and mRNA analysis (Reubi et al 1994b, Kubota et al 1994, Vikic et al 1995, Reubi et al 1998, Janson et al 1998, Kimura et al 1999, Papotti et al 2000, 2001a, 2001b, 2002, Kulaksiz et al 2002, Korner et al 2005). A wide heterogeneity of sst subtypes expression across the different tumour types, as well as within a single tumour sample, has been reported. In most cases, sst 2 is the most largely represented, even if individual tumours co-express different sst subtypes [Figure 1d]. Such high heterogeneity in ssts distribution partially explains the discrepancies in the clinical features and response to SS analogue therapy observed in neuroendocrine tumours originated from different sites. With regard to the ssts distribution, only selected issues will be discussed in here because of space constraints.

Pituitary adenomas and well-differentiated endocrine tumours (so called benign or malignant "carcinoids") of the gastro-entero-pancreatic (GEP) region represent a major target for SS-analogue clinical applications (Oberg 2002, Oberg et al 2004, Falconi et al 2006, Butturini et al 2006, O'Toole et al 2006, Batista et al 2006). The reported data on over 700 neuroendocrine GEP tumours analyzed applying different techniques, demonstrated a high expression of ssts, with the exception of sst4, without a relevant correlation between the subtype(s) expressed and the histological diagnosis. At the same time, no correlation of the different sst subtypes has been reported with the locations of the primary tumour, whereas few data support a specific association with hormone secretion (i.e. 100\% expression of sst2 in gastrinomas of the duodeno-pancreatic region) (Reubi et al 1998, Papotti et al 2002).

Ssts are also widely represented in neuroendocrine tumours of the lung, both well- or poorlydifferentiated, as revealed by in vivo studies, with a preferential expression of sst subtypes 2,3 and 5 (Berenger et al 1996, Reisenger et al 1998) and localization (Janson et al 1996, Reubi et al 1996, Papotti et al 2000, Papotti et al 2001a, Hofland et al 1999, Reubi et al 1998, Reubi et al 2000b).

Evidence of ssts expression in medullary thyroid carcinomas is based on both binding (Reubi et al 1991), in vivo scintigraphic (Kwekkebom et al 1993), mRNA (Mato et al 1998, Zatelli et al 2006) and immunohistochemical (Papotti et al 2001b) studies, the latter two having detected the presence of all but sst4 subtypes. Interestingly, medullary thyroid carcinoma was also found to produce SS (Papotti et al 2001b, Mato et al 1998, Pacini et al 1991): possible autocrine/paracrine circuits may be active in this tumor, especially in view of the fact that the presence of somatostatinpositive medullary thyroid carcinoma cells is associated with a more favorable prognosis (Pacini et al 1991). 


\section{Expression and localization of SS receptors in non-neuroendocrine tumours}

A wide spectrum of solid or hematological malignancies have been demonstrated to variably express ssts (Patel 1997, Hofland et al 2003, Reubi et al 2000a). Among epithelial tumours, a variety of carcinomas showed clinical and tissue localization-based evidence of sst expression: such tumours include breast (Papotti et al 1989, Vikic et al 1995, Reubi et al 2002), lung (Papotti et al 2000 and 2001a), renal (Vikic et al 1995), pancreato-biliary tract (Zhao et al 2002, Pilikowska et al 2001), liver cell (Dimitropoulos et al 2002), colorectal (Laws 1997, Qiu et al 2006), ovarian (Hall et al 2002), follicular thyroid (Haslunguis et al 2001), and prostatic (Reubi et al 1995, Dizey et al 2002) carcinomas. In some of these cases, an antiproliferative activity of SS analogs could be demonstrated (Haslinguis et al 2001, Wang et al 2003, Guillermet et al 2003, Vernejoul et al 2002), particularly in hormone independent prostatic carcinomas at advanced stages (Vainas et al 2001, Plonowski et al 1999). Sst subtypes have also been detected in meningiomas and gliomas, in soft tissues sarcomas and in malignant melanomas; this distribution correlated with either scintigraphic imaging or in vitro tests on SS analogue response (Reubi et al 1987, Doutur et al 1998, Friedberg et al 1999, Lum et al 2001). Promising clinical applications of SS analogs have also been reported in lympho-hematological malignancies (Ferone et al 2001a, Lugtenburg et al 2001) and in thymomas (Ferone et al 2001b, Lastoria et al 1998).

\section{Specific cortistatin receptor expression in tumours}

Theoretically, all the above described binding sites for SS are also shared by CST, although a precise definition of the binding affinity of this latter in the various tumours is still lacking. CST interaction with ssts, GHS-R1a and the formerly orphan receptor MrgX2, claimed to be CST specific, complicates the identification of which receptor mediates a specific CST activity. MrgX2 has been identified in dorsal ganglia and in hippocampal neurons (but not in the cerebral cortex) and found to possess a high affinity for CST-14 (Robas et al 2003). This receptor does not bind SS, despite the partial homology with CST, due to the lack of two crucial aminoacids, a N-terminal proline and a C-terminal lysine, which are present in the CST aminoacid sequence, only. In peripheral tissues, weak immunohistochemical reactivity for MrgX2 was originally reported in endothelial cells and testis (Robas et al 2003), but no data are available on its distribution in other normal and neoplastic tissues. On the other side, CST was reported to play a role in the growth control of thyroid tumour (Cassoni et al 2002) and liver (Notas et al 2004) carcinoma cell lines. Therefore, to identify possible targets of CST action, the MrgX2 distribution was studied in our laboratory in a large series of human tissues and related endocrine and non-endocrine tumours (Allia et al 2005). With regard to endocrine tumours, MrgX2 mRNA was detected in 8/24 cases by means of RT PCR, generally with a weak signal. These included seven neuroendocrine tumours of 
the pancreas, intestine and lung, and one single case of pheochromocytoma. However, immunohistochemistry revealed that MrgX2 expression was restricted to peritumoural blood vessels, ganglia and lymphocytes, whereas the neoplastic component was negative in all 24 tumours samples investigated. In addition, control non-neuroendocrine tumours (3 pancreatic and 3 gastrointestinal adenocarcinomas, 2 seminomas and 1 papillary thyroid carcinoma) did not express nor MrgX2 mRNA neither the protein (Allia et al 2005). In another study on 41 lung tumours, approximately $30 \%$ of neuroendocrine and $60 \%$ of non-neuroendocrine neoplasias were found to contain MrgX2 mRNA by RT-PCR. The same samples also were positive for CST (both mRNA and the protein) (Cassoni et al 2006). Based on the MrgX2 protein preferential localization in blood vessels of peripheral tissues, it seems that the effects of CST in tumours are rather mediated via ssts (or the ghrelin receptor). In this line, a recent study (Rubinfield et al 2006) showed that CST has the ability of reducing growth hormone and prolactin release by pituitary functioning adenoma cells, preferentially binding to the sst type 5 .

Finally, the presence of MrgX2 in lymphocytes deserves further studies to clarify which is the role of CST binding in the immune cells: it has been suggested, in fact, that in addition to ssts, other receptors may partially mediate CST activities in these cells, including the GHS-R1a (Gonzalez-Rey et al 2007). In the past few years, a number of reports have proposed therapeutic activities for CST in inflammation. Among these, compelling evidence came from Delgado's group (Gonzalez-Rey et al 2006a and 2006b, Gonzalez-Rey et al 2007), highlighting CST therapeutic potential in different murine models of inflammatory diseases, including lethal endotoxemia, inflammatory bowel disease and arthritis. Treatment with CST prevented the development of the inflammatory reaction and reduced the severity of symptoms (Gonzalez-Rey et al 2006a and 2006b, Gonzalez-Rey et al 2007). CST activity relied on the inhibition of macrophages activation and on both Th1 lymphocytes humoural response and proliferation. On these basis, it would be of great interest to investigate whether CST, in analogy with the above-mentioned SS analogs, has an effect on intratumoral immune cells, with regard to both solid tumors and hematological malignancies.

\section{EFFECTS ON TUMOUR CELL GROWTH}

Certainly, we know better the effects on cancer growth of SS rather than CST. A long lasting experience has been accumulated with the employment of SS analogs for diagnostic and therapeutic purposes, as opposed to CST analogs, which are currently under investigation. A recent commentary (Grimberg 2004) has summarized the effects of SS on cancer cells through different mechanisms, including a) a normal endocrine activity via the GH-IGF1 axis, b) inhibition of 
angiogenesis, c) modulation of the immune response to tumour cells, and d) direct signalling on tumour cells via SS receptors. This latter property is at the basis of diagnostic procedures and therapies which directly target tumour cells (Oberg et al 2004).

SS analogs were synthesized on the basis of structural and functional data on SS-14, showing that aminoacidic residues in positions 7-10 were fundamental for its biological activity (Raynor et al 1993b). Among the numerous designed hexa- and octa-peptides, the latter, for example octreotide and lanreotide, have a high affinity for sst types 2, 3 and 5 and are registered in most countries for clinical use (deHerder \& Lamberts 2002). New synthetic analogs possessing high affinity for all sst subtypes are currently being investigated, for instance the cyclic hexapeptide pasireotide (SOM230) (Lewis et al 2003). Synthetic SS analogs are used for hormonal treatments (possibly associated with other drugs), since they may control hormone secretion and also possess an antiproliferative action. In addition, SS analogs labeled with ${ }^{111}$ Indium can be used to visualize sst positive tumours in vivo, using gamma camera images. These same SS analogs after appropriate modifications can be used as a vehicle of either chemotherapeutic or radioactive agents for the treatment of sst positive tumours (Smith et al 2000, deJong et al 2001). More recently, the combined action of SS/dopamine chimeric molecules on both SS and dopamine receptors opened the way to additional therapeutic strategies, based on the co-expression of these receptors in several normal and neoplastic human cell systems and on their synergy in cell growth control (Ferone et al 2005, Jaquet et al 2005, Saveanu et al 2006, O'Toole et al 2006).

The prolonged exposure of sst positive tissues or tumours to SS analogs may cause adaptation or tachyphylaxis processes which determine a diminution of patient's response due to different mechanisms including receptor phosphorylation, internalization and degradation (Lamberts et al 1996, Patel 1999) as well as selection of sst-negative or sst unresponsive or sst gene mutated cell clones (Reubi et al 1992a, Zhang et al 1995, Ballare et al 2001). The resistance to SS analogs is extremely variable in different tumours and may affect hormone secretion and/or antiproliferative effects (Lamberts et al 1986, 1988 and 1996; Koper et al 1990, Mahy et al 1988, Srikant et al 1985). In such condition it would be of interest to monitor whether CST and its analogs may fully or partly restore the patient's responsiveness to treatment, or on the contrary, act exactly as a SS analog.

The effects of CST in tumour models are only partially overlapping to those of SS (and of ghrelin, whose receptors are also recognized by CST). In functional pituitary adenomas, CST was shown able to inhibit growth hormone and prolactin release, as SS does, indicating a similar ability to control hormonal secretion via SS receptors (Rubinfield et al 2006, Grottoli et al 2006). In the small cell lung carcinoma H345 cell line, CST did not show any antiproliferative effect, as opposed to ghrelin which induced a dose-dependent inhibition of cell proliferation (Cassoni et al 2006). In thyroid tumour cell lines of follicular and parafollicular origin, microMolar concentrations of CST 
determined a significant dose-dependent inhibition of cell proliferation, an effect that was more pronounced than that of SS-14 (Cassoni et al 2002). Finally, CST (but not SS) mRNA was detected in a hepatocellular carcinoma cell line, in association with sst(s) mRNA. Since octreotide was shown to inhibit cell proliferation of these cells, an autocrine effect via SS receptors, sustained by CST rather than by SS, most likely takes place in this in vitro model (Notas et al 2004). Hexa- and octapeptide analogs of CST have been constructed (Deghenghi et al 2003), and some of them (CST8) studied for GH (Luque et al 2006) and gastric acid secretion (Sibilia et al 2006); the agonist and antagonist effects of such compounds on cell proliferation may need to be investigated in tumour models, to ascertain whether the CST pathway can be as effective as that of SS in reducing hormonal secretion and cell growth in neuroendocrine tumours.

\section{CONCLUSIONS}

The knowledge about the somatostatin-like ligands and their receptors has recently been implemented with the identification of cortistatin and of its ability to interact with both the ghrelin receptor GHSR1a and the cortistatin receptor MrgX2. Mapping the distribution profiles of these proteins has indicated that ssts are widely expressed in several human neuroendocrine and nonneuroendocrine tumours, the ghrelin receptor is present in many neuroendocrine and non neuroendocrine tumours, while MrgX2 has not been localized in any tumour, yet. Both SS and CST were identified in several benign and malignant neuroendocrine tumours/carcinoids (gastrointestinal tract, pancreas, lung) as well as in pheochromocytomas, parathyroid tumours, medullary thyroid carcinomas, and Merkel cell carcinomas, often co-localizing with their receptors. If the effects of SS and its synthetic analogs can be related tospecific ss receptor subtypes, conversely, we speculate thatCST actions (including the antiproliferative effects demonstrated in tumour cell lines) are mediated by distinct sst subtypes and/or by the ghrelin receptor GHS-R1a, since all the above tumours consistently lacked MrgX2. However we cannot exclude that additional receptors for CST may also exhist, which are expressed in peripheral tissues and are currently unidentified yet. In this intricated network of well-characterized as well as unknown receptors on one side, and different ligands on the other, it appears that CST, beside SS, may have major effects on neuroendocrine tumor growth control. This may be the result of a direct anti-proliferative action and/or modulation of the immune response by CST. Based on the experience gained with SS octapeptide analogs, the development of synthetic CST analogs might open new interesting perspectives in the treatment of neuroendocrine tumors, by either selectively targeting CST-specific receptor subtypes or combining and potentiating the effects of the better known SS analogs. 


\section{ACKNOWLEDGEMENTS}

The authors wish to thank Prof. Romano Deghenghi for his precious and enthusiastic suggestions in these studies. 


\section{REFERENCES}

Allia, E., Tarabra, E., Volante, M., Cerrato, M., Ghigo, E., Muccioli, G., Papotti, M., 2005. Expression of cortistatin and MrgX2, a specific cortistatin receptor, in human neuroendocrine tissues and related tumours. J. Pathol. 207, 336-345.

Ballare, E., Persani, L., Lania, A.G., Filopanti, M., Giammona, E., Corbetta, S., Mantovani, S., Arosio, M., Beck-Peccoz, P., Faglia, G., Spada, A., 2001. Mutation of somatostatin receptor type 5 in an acromegalic patient resistant to somatostatin analog treatment. J. Clin. Endocrinol. Metab. 86, 3809-3814.

Batista, D.L., Zhang, X., Gejman, R., Ansell, P.J., Zhou, Y., Johnson, S.A., Swearingen, B., HedleyWhyte, E.T., Stratakis, C.A., Klibanski, A., 2006. The effects of SOM230 on cell proliferation and adrenocorticotropin secretion in uman corticotroph pituitary adenomas. J. Clin. Endocrinol. Metab. 91, 44824488 .

Berenger, N., Moretti, J.L., Boaziz, C., Vigneron, N., Morere, J.F., Breau, J.L., 1996. Somatostatin receptor imaging in small cell lung cancer. Eur. J. Cancer. 32, 1429-1431.

Bloom, S.R., Mortimer, C.H., Thorner, M.O., Besser, G.M., Hall, R., Gomez-Pan, A., Roy, V.M., Russell, R.C., Coy, D.H., Kastin, A.J., Schally, A.V., 1974. Inhibition of gastrin and gastric-acid secretion by growth-hormone release-inhibiting hormone. Lancet. 2, 1106-1109.

Bloom, S.R., Ralphs, D.N., Besser, G.M., Hall, R., Coy, D.H., Kastin, A.J., Schally, A.V., 1975. Proceedings: Effect of somatostatin on motilin levels and gastric emptying. Gut. 16, 834-834.

Bousquet, C., Puente, E., Buscail, L., Vaysse, N., Susini, C., 2001. Antiproliferative effect of somatostatin and analogs. Chemotherapy. 47, 30-39.

Broglio, F., Arvat, E., Benso, A., Gottero, C., Prodam, F., Grottoli, S., Papotti, M., Muccioli, G., Van der Lely, A.J., Deghenghi, R., Ghigo, E., 2002. Endocrine activities of cortistatin-14 and its interaction with GHRH and ghrelin in humans. J. Clin. Endocrinol. Metab. 87, 3783-3790.

Butturini, G., Bettini, R., Missiaglia, E., Mantovani, W., Dalai, I., Capelli, P., Ferdeghini, M., Pederzoli, P., Scarpa, A., Falconi, M., 2006. Predictive factors of efficacy of the somatostatin analogue octreotide as first line therapy for advanced pancreatic endocrine carcinoma. Endocr. Relat. Cancer. 13, 1213-1221.

Cassoni, P., Allia, E., Marrocco, T., Ghe, C., Ghigo, E., Muccioli, G., Papotti, M., 2006. Ghrelin and cortistatin in lung cancer: expression of peptides and related receptors in human primary tumours and in vitro effect on the H345 small cell carcinoma cell line. J. Endocrinol. Invest. 29, 781-790.

Cassoni, P., Muccioli, G., Marrocco, T., Volante, M., Allia, E., Ghigo, E., Deghenghi, R., Papotti, M., 2002. Cortistatin-14 inhibits cell proliferation of human thyroid carcinoma cell lines of both follicular and parafollicular origin. J. Endocrinol. Invest. 25, 362-368.

Cescato, R., Schulz, S., Waser, B., Eltschinger, V., Rivier, J.E., Wester, H.J., Culler, M., Ginj, M., Liu, Q., Schonbrunn, A., Reubi, J.C., 2006. Internalization of sst2, sst3, and sst5 receptors: effects of somatostatin agonists and antagonists. J. Nucl. Med. 47, 502-511.

Dalm, V.A., van Hagen, P.M., van Koetsveld, P.M., Achilefu, S., Houtsmuller, A.B., Pols, D.H., van der Lely, A.J., Lamberts, S.W., Hofland, L.J., 2003a. Expression of somatostatin, cortistatin, and somatostatin receptors in human monocytes, macrophages, and dendritic cells. Am. J. Physiol. Endocrinol. Metab. 285, E344-353.

Dalm, V.A., Van Hagen, P.M., de Krijger, R.R., Kros, J.M., Van Koetsveld, P.M., Van Der Lely, A.J., Lamberts, S.W., Hofland, L.J., 2004. Distribution pattern of somatostatin and cortistatin mRNA in human central and peripheral tissues. Clin. Endocrinol. 60, 625-629.

Dalm, V.A., Van Hagen, P.M., Van Koetsveld, P.M., Langerak, A.W., Van Der Lely, A.J., Lamberts, S.W., Hofland, L.J., 2003b. Cortistatin rather than somatostatin as a potential endogenous ligand for somatostatin receptors in the human immune system. J. Clin. Endocrinol. Metab. 88, 270-276.

Dayal, Y., Oberg, K., Perren, A., Komminoth, P., 2004. Somatostatinoma. In: De Lellis, R.A., Lloyd, R.V., Heitz, Ph.U., Eng, C. (eds): WHO Classification of Tumours. Pathology \& Genetics. Tumours of the endocrine organs. IARC Press, Lyon, pp. 189-190.

De Herder, W.W, Lamberts, S.W., 2002. Somatostatin and somatostatin analogs: diagnostic and therapeutic uses. Curr. Opin. Oncol. 14, 53-57.

De Jong, M., Breeman, W.A., Bernard, B.F., Bakker, W.H., Schaar, M., van Gameren, A., Bugaj, J.E., Erion, J., Schmidt, M., Srinivasan, A., Krenning, E.P., 2001. [177Lu-DOTA(0),Tyr3] octreotate for somatostatin receptor-targeted radionuclide therapy. Int. J. Cancer. 92, 628-633.

De Lecea, L., Castano, J.P., 2006. Cortistatin: not just another somatostatin analog. Nat. Clin. Pract. Endocrinol. Metab. 2, 356-357. 
De Lecea, L., Criado, J.R., Prospero-Garcia, O., Gautvik, K.M., Schweitzer, P., Danielson, P.E., Dunlop, C.L., Siggins, G.R., Henriksen, S.J., Sutcliffe, J.G., 1996. A cortical neuropeptide with neuronal depressant and sleep-modulating properties. Nature. 381, 242-245.

De Lecea, L., Ruiz-Lozano, P., Danielson, P.E., Peelle-Kirley, J., Foye, P.E., Frankel, W.N., Sutcliffe, J.G., 1997. Cloning, mRNA expression, and chromosomal mapping of mouse and human preprocortistatin. Genomics. 42, 499-506.

Deghenghi, R., Broglio, F., Papotti, M., Muccioli, G., Ghigo, E., 2003. Targeting the ghrelin receptor. Orally active GHS and cortistatin analogs. Endocrine. 22, 13-18.

Deghenghi, R., Papotti, M., Ghigo, E., Muccioli, G., 2001. Cortistatin, but not somatostatin, binds to growth hormone secretagogue (GHS) receptor of human pituitary gland. J. Endocrinol. Invest. 24, RC1-RC3.

DeLellis, R.A., Lloyd, R.V., Heitz, Ph.U., Eng, C., 2004. World Health Organisation Classification of tumors. Pathology \& Genetcis: Tumors of endocrine organs. IARC Press, Lyon, pages 185-190.

Dimitroulopoulos, D., Xinopoulos, D., Tsamakidis, K., Zisimopoulos, A., Andriotis, E., Markidou, S., Panagiotakos, D., Chrysohoou, C., Bazinis, A., Paraskevas, E., 2002. The role of sandostatin LAR in treating patients with advanced hepatocellular cancer. Hepatogastroenterology. 49, 1245-1250.

Dizeyi, N., Konrad, L., Bjartell, A., Wu, H., Gadaleanu, V., Hansson, J., Helboe, L., Abrahamsson, P.A., 2002. Localization and mRNA expression of somatostatin receptor subtypes in human prostatic tissue and prostate cancer cell lines. Urol. Oncol. 7, 91-98.

Dutour, A., Kumar, U., Panetta, R., Ouafik, L., Fina, F., Sasi, R., Patel, Y.C., 1998. Expression of somatostatin receptor subtypes in human brain tumours. Int. J. Cancer. 76, 620-627.

Epelbaum, J., 1986. Somatostatin in the central nervous system: physiology and pathological modifications. Prog. Neurobiol. 27, 63-100.

Falconi, M., Plockinger, U., Kwekkeboom, D.J., Manfredi, R., Korner, M., Kvols, L., Pape, U.F., Ricke, J., Goretzki, P.E., Wildi, S., Steinmuller, T., Oberg, K., Scoazec, J.Y., 2006. Frascati Consensus Conference; European Neuroendocrine Tumour Society. Well-differentiated pancreatic non-functioning tumours/carcinoma. Neuroendocrinology. 84, 196-211.

Fedele, M., De Martino, I., Pivonello, R., Ciarmiello, A., Del Basso De Caro, M.L., Visone, R., Calmieri, D., Pierantoni, G.M., Arra, C., Schmid, H.A., Hofland, L., Lombardi, G., Colao, A., Fusco, A. 2007., SOM230, a new somatostatin analogue, is highly effective in the therapy of growth hormone/prolactin-secreting pituitary adenomas. Clin. Cancer Res. 13, 2738-2744.

Ferone, D., Arvigo, M., Semino, C., Jaquet, P., Saveanu, A., Taylor, J.E., Moreau, J.P., Culler, M.D., Albertelli, M., Minuto, F., Barreca, A., 2005. Somatostatin and dopamine receptor expression in lung carcinoma cells and effects of chimeric somatostatin-dopamine molecules on cell proliferation. Am. J. Physiol. Endocrinol. Metab. 289, E1044-1050.

Ferone, D., Boschetti, M., Resmini, E., Giusti, M., Albanese, V., Goglia, U., Albertelli, M., Vera, L., Bianchi, F., Minuto, F., 2006. Neuroendocrine-immune interactions: the role of cortistatin/somatostatin system. Ann. N.Y. Acad. Sci. 1069, 129-144.

Ferone, D., Hofland, L.J., Colao, A., Lamberts, S.W., van Hagen, P.M., 2001a. Neuroendocrine aspects of immunolymphoproliferative diseases. Ann. Oncol. 12, S125-130.

Ferone, D., Kwekkeboom, D.J., Pivonello, R., Bogers, A.D., Colao, A., Lamberts, S.W., van Hagen, P.M., Hofland, L.J., 2001b. In vivo and in vitro expression of somatostatin receptors in two human thymomas with similar clinical presentation and different histological features. J. Endocrinol. Invest. 24, 522-528.

Friedberg, J.W., Van den Abbeel,e A.D., Kehoe, K., Singer, S., Fletcher, C.D., Demetri, G.D., 1999. Uptake of radiolabeled somatostatin analog is detectable in patients with metastatic foci of sarcoma. Cancer. 86, 1621-1627.

Fukusumi, S., Kitada, C., Takekawa, S., Kizawa, H., Sakamoto, J., Miyamoto, M., Hinuma, S., Kitano, K., Fujino, M., 1997. Identification and characterization of a novel human cortistatin-like peptide. Biochem. Biophys. Res. Commun. 232, 157-163.

Gonzalez-Rey, E., Chorny, A., Del Moral, R.G., Varela, N., Delgado, M., 2007. Therapeutic effect of cortistatin on experimental arthritis by downregulating inflammatory and Th1 responses. Ann. Rheum. Dis. $66,582-588$.

Gonzalez-Rey, E, Varela, N, Sheibanie, AF, Chorny, A, Ganea, D, Delgado, M., 2006a. Cortistatin, an antiinflammatory peptide with therapeutic action in inflammatory bowel disease. Proc. Natl. Acad. Sci. U.S.A. 103, 4228-4233.

Gonzalez-Rey, E., Chorny, A., Robledo, G., Delgado, M., 2006b. Cortistatin, a new antiinflammatory peptide with therapeutic effect on lethal endotoxemia. J. Exp. Med. 203, 563-571. 
Gottero, C., Prodam, F., Destefanis, S., Benso, A., Gauna, C., Me, E., Filtri, L., Riganti, F., Van Der Lely, A.J., Ghigo, E., Broglio, F., 2004. Cortistatin-17 and -14 exert the same endocrine activities as somatostatin in humans. Growth Horm IGF Res. 14, 382-387.

Grimberg, A., 2004. Somatostatin and cancer: applying endocrinology to oncology. Cancer. Biol. Ther. 3, 731-733.

Grottoli, S., Gasco, V., Broglio, F., Baldelli, R., Ragazzoni, F., Gallenca, F., Mainolfi, A., Prodam, F., Muccioli, G., Ghigo, E., 2006. Cortistatin-17 and somatostatin-14 display the same effects on growth hormone, prolactin, and insulin secretion in patients with acromegaly or prolactinoma. J. Clin. Endocrinol. Metab. 91, 1595-1599.

Guillermet, J., Saint-Laurent, N., Rochaix, P., Cuvillier, O., Levade, T., Schally, A.V., Pradayrol, L., Buscail, L., Susini, C., Bousquet, C., 2003. Somatostatin receptor subtype 2 sensitizes human pancreatic cancer cells to death ligand-induced apoptosis. Proc. Natl. Acad. Sci. U. S. A. 100, 155-160.

Hall, G.H., Turnbull, L.W., Richmond, I., Helboe, L., Atkin, S.L., 2002. Localisation of somatostatin and somatostatin receptors in benign and malignant ovarian tumours. Br. J. Cancer. 87, 86-90.

Hamy, A., Heymann, M.F., Bodic, J., Visset, J., Le Borgne, J., Leneel, J.C., Le Bodic, M.F., 2001. Duodenal somatostatinoma. Anatomic/clinical study of 12 operated cases. Ann. Chir. 126, 221-226.

Haslinghuis, L.M., Krenning, E.P., De Herder, W.W., Reijs, A.E., Kwekkeboom, D.J., 2001. Somatostatin receptor scintigraphy in the follow-up of patients with differentiated thyroid cancer. J. Endocrinol. Invest. 24, 415-422.

Hofland, L.J., van der Hoek, J., Feelders, R., van der Lely, A.J., de Herder, W., Lamberts, S.W., 2005. Pre-clinical and clinical experiences with novel somatostatin ligands: advantages, disadvantages and new prospects. J. Endocrinol. Invest.28S,36-42.

Hofland, L.J., Lamberts. SW., 2003. The pathophysiological consequences of somatostatin receptor internalization and resistance. Endocr. Rev. 24, 28-47.

Hofland, L.J., Liu, Q., Van Koetsveld, P.M., Zuijderwijk, J., Van Der Ham, F., de Krijger, R.R., Schonbrunn, A., Lamberts, S.W., 1999. Immunohistochemical detection of somatostatin receptor subtypes sst1 and sst2A in human somatostatin receptor positive tumours. J. Clin. Endocrinol. Metab. 84, 775-780.

Hoyer, D., Bell, G.I., Berelowitz, M., Epelbaum, J., Feniuk, W., Humphrey, P.P., O'Carroll, A.M., Patel, Y.C., Schonbrunn, A., Taylor, J.E., et al., 1995. Classification and nomenclature of somatostatin receptors. Trends Pharmacol. Sci. 16, 86-88.

Hu, C., Yi, C., Hao, Z., Cao, S., Li, H., Shao, X., Zhang, J., Qiao, T., Fan, D., 2004. The effect of somatostatin and sst3 on proliferation and apoptosis of gastric cancer cells. Cancer Biol. Ther. 3, 726-730.

Hukovic, N., Panetta, R., Kumar, U., Patel, Y.C., 1996. Agonist-dependent regulation of cloned human somatostatin receptor types 1-5 (hsst1-5): subtype selective internalization or upregulation. Endocrinology.137, 4046-4049.

Janson, E.T., Gobl, A., Kalkner, K.M., Oberg, K., 1996. A comparison between the efficacy of somatostatin receptor scintigraphy and that of in situ hybridization for somatostatin receptor subtype 2 messenger RNA to predict therapeutic outcome in carcinoid patients. Cancer Res. 56, 2561-2565.

Janson, E.T., Stridsberg, M., Gobl, A., Westlin, J.E., Oberg, K., 1998. Determination of somatostatin receptor subtype 2 in carcinoid tumours by immunohistochemical investigation with somatostatin receptor subtype 2 antibodies. Cancer Res. 58, 2375-2378.

Jaquet, P., Gunz, G., Saveanu, A., Dufour, H., Taylor, J., Dong, J., Kim, S., Moreau, J.P., Enjalbert, A., Culler, M.D., 2005. Efficacy of chimeric molecules directed towards multiple somatostatin and dopamine receptors on inhibition of $\mathrm{GH}$ and prolactin secretion from GH-secreting pituitary adenomas classified as partially responsive to somatostatin analog therapy. Eur. J. Endocrinol. 153, 135-141.

Kaltsas, G.A., Papadogias, D., Makras, P., Grossman, A.B., 2005. Treatment of advanced neuroendocrine tumours with radiolabelled somatostatin analogues. Endocr. Relat. Cancer. 12, 683-699.

Kamohara, M., Matsuo, A., Takasaki, J., Kohda, M., Matsumoto, M., Matsumoto, S., Soga, T., Hiyama, H., Kobori, M., Katou, M., 2005. Identification of MrgX2 as a human G-protein-coupled receptor for proadrenomedullin N-terminal peptides. Biochem. Biophys. Res. Commun. 330, 1146-1152.

Kimura, N., Pilichowska, M., Date, F., Kimura, I., Schindler, M., 1999. Immunohistochemical expression of somatostatin type 2A receptor in neuroendocrine tumours. Clin. Cancer. Res. 5, 3483-3487.

Kogner, P., Borgstrom, P., Bjellerup, P., Schilling, F.H., Refai, E., Jonsson, C., Dominici, C., Wassberg, E., Bihl, H., Jacobsson, H., Theodorsson, E., Hassan, M., 1997. Somatostatin in neuroblastoma and ganglioneuroma. Eur. J. Cancer. 33, 2084-2089. 
Koper, J.W., Hofland, L.J., van Koetsveld, P.M., den Holder, F., Lamberts, S.W., 1990. Desensitization and resensitization of rat pituitary tumour cells in long-term culture to the effects of the somatostatin analogue SMS 201-995 on cell growth and prolactin secretion. Cancer Res. 50, 6238-6242.

Korner, M., Eltschinger, V., Waser, B., Schonbrunn, A., Reubi, J.C., 2005. Value of immunohistochemistry for somatostatin receptor subtype sst2A in cancer tissues: lessons from the comparison of anti-sst2A antibodies with somatostatin receptor autoradiography. Am. J. Surg. Pathol. 29, 1642-1651.

Kreienkamp, H.J., 1999. Molecular biology of the receptors for somatostatin and cortistatin. Results Probl. Cell. Differ. 26, 215-237.

Krulich, L., Dhariwal, A.P., McCann, S.M., Krulich, L., Dhariwal, A.P., McCann, S.M., 1968. Stimulatory and inhibitory effects of purified hypothalamic extracts on growth hormone release from rat pituitary in vitro. Endocrinology. 83, 783-790.

Kubota, A., Yamada, Y., Kagimoto, S., Shimatsu, A., Imamura, M., Tsuda, K., Imura, H., Seino, S., Seino, Y., 1994. Identification of somatostatin receptor subtypes and an implication for the efficacy of somatostatin analogue SMS 201-995 in treatment of human endocrine tumours. J. Clin. Invest. 93, 13211325.

Kulaksiz, H., Eissele, R., Rossler, D., Schulz, S., Hollt, V., Cetin, Y., Arnold, R., 2002. Identification of somatostatin receptor subtypes $1,2 \mathrm{~A}, 3$, and 5 in neuroendocrine tumours with subtype specific antibodies. Gut. 50, 52-60.

Kwekkeboom, D.J., Reubi, J.C., Lamberts, S.W., Bruining, H.A., Mulder, A.H., Oei, H.Y., Krenning, E.P., 1993. In vivo somatostatin receptor imaging in medullary thyroid carcinoma. J. Clin. Endocrinol. Metab. 76, 1413-1417.

Lamberts, S.W., 1988. The role of somatostatin in the regulation of anterior pituitary hormone secretion and the use of its analogs in the treatment of human pituitary tumours. Endocr. Rev. 9, 417-436.

Lamberts, S.W., Krenning, E.P., Reubi, J.C., 1991. The role of somatostatin and its analogs in the diagnosis and treatment of tumours. Endocr. Rev. 12, 450-482.

Lamberts, S.W., Reubi, J.C., Uiterlinden, P., Zuiderwijk, J., van den Werff, P., van Hal, P., 1986. Studies on the mechanism of action of the inhibitory effect of the somatostatin analog SMS 201-995 on the growth of the prolactin/adrenocorticotropin-secreting pituitary tumour 7315a. Endocrinology. 118, 2188-2194.

Lamberts, S.W., van der Lely, A.J., de Herder, W.W., Hofland, L.J., 1996. Octreotide. N. Engl. J. Med. 334, 246-254.

Lastoria, S., Vergara, E., Palmieri, G., Acampa, W., Varrella, P., Caraco, C., Bianco, R.A., Muto, P., Salvatore, M., 1998. In vivo detection of malignant thymic masses by indium-111-DTPA-D-Phe1-octreotide scintigraphy. J. Nucl. Med. 39, 634-639.

Laws, S.A., Gough, A.C., Evans, A.A., Bains, M.A., Primrose, J.N., 1997. Somatostatin receptor subtype mRNA expression in human colorectal cancer and normal colonic mucosae. Br. J. Cancer. 75, 360-366.

Lewis, I., Bauer, W., Albert, R., Chandramouli, N., Pless, J., Weckbecker, G., Bruns, C., 2003. A novel somatostatin mimic with broad somatotropin release inhibitory factor receptor binding and superior therapeutic potential. J. Med. Chem. 46, 2334-2344.

Liu, Q., Cescato, R., Dewi, D.A., Rivier, J., Reubi, J.C., Schonbrunn, A., 2005. Receptor signaling and endocytosis are differentially regulated by somatostatin analogs. Mol. Pharmacol. 68, 90-101.

Low, M.J., 2004. The somatostatin neuroendocrine system: physiology and clinical relevance in gastrointestinal and pancreatic disorders. Best Pract. Res. Clin. Endocrinol. Metab. 18, 607-622.

Lugtenburg, P.J., Krenning, E.P., Valkema, R., Oei, H.Y., Lamberts, S.W., Eijkemans, M.J., van Putten, W.L., Lowenberg, B., 2001. Somatostatin receptor scintigraphy useful in stage I-II Hodgkin's disease: more extended disease identified. Br. J. Haematol. 112, 936-944.

Lum, S.S., Fletcher, W.S., O'Dorisio, M.S., Nance, R.W., Pommier, R.F., Caprara, M., 2001. Distribution and functional significance of somatostatin receptors in malignant melanoma. World J. Surg. 25, 407-412.

Luque, R.M., Peinado, J.R., Gracia-Navarro, F., Broglio, F., Ghigo, E., Kineman, R.D., Malagon, M.M., Castano, J.P., 2006. Cortistatin mimics somatostatin by inducing a dual, dose-dependent stimulatory and inhibitory effect on growth hormone secretion in somatotropes. J. Mol. Endocrinol. 36,547-556.

Mahy, N., Woolkalis, M., Manning, D., Reisine, T., 1988. Characteristics of somatostatin desensitization in the pituitary tumour cell line AtT-20. J. Pharmacol. Exp. Ther. 247, 390-396.

Mao, J.D., Wu, P., Xia, X.H., Hu, J.Q., Huang, W.B., Xu, G.Q., 2005. Correlation between expression of gastrin, somatostatin and cell apoptosis regulation gene bcl-2/bax in large intestine carcinoma. World J. Gastroenterol. 11, 721-725. 
Mato, E., Matias-Guiu, X., Chico, A., Webb, S.M., Cabezas, R., Berna, L., De Leiva, A., 1998. Somatostatin and somatostatin receptor subtype gene expression in medullary thyroid carcinoma. J. Clin. Endocrinol. Metab. 83, 2417-2420.

Mawrin, C., Schulz, S., Hellwig-Patyk, A., Kirches, E., Roessner, A., Lendeckel, U., Firsching, R., Vorwerk, C.K., Keilhoff, G., Dietzmann, K., Grimm, K., Lindberg, G., Gutmann, D.H., Scheithauer, B.W., Perry, A., 2005. Expression and function of somatostatin receptors in peripheral nerve sheath tumours. J. Neuropathol. Exp. Neurol. 64, 1080-1088.

Moayedoddin, B., Booya, F., Wermers, R.A., Lloyd, R.V., Rubin, J., Thompson, G.B., Fatourechi, V., 2006. Spectrum of malignant somatostatin-producing neuroendocrine tumours. Endocr. Pract. 12, 394-400.

Notas, G., Kolios, G., Mastrodimou, N., Kampa, M., Visilaki, A., Xidakis, C., Castanas, E., Thermos, K., Kouroumalis, E., 2004. Cortistatin production by HepG2 human hepatocellular carcinoma cell line and distribution of somatostatin receptors. J. Hepatol. 40, 792-798.

Oberg, K., 2002. Carcinoid tumours: molecular genetics, tumour biology, and update of diagnosis and treatment. Curr. Opin. Oncol. 14, 38-45.

Oberg, K., Kvols, L., Caplin, M., Delle Fave, G., de Herder, W., Rindi, G., Ruszniewski, P., Woltering, E.A., Wiedenmann, B., 2004. Consensus report on the use of somatostatin analogs for the management of neuroendocrine tumours of the gastroenteropancreatic system. Ann. Oncol. 15, 966-973.

Ohike, N., Jurgensen, A., Pipeleers-Marichal, M., Kloppel, G., 2003. Mixed ductal-endocrine carcinomas of the pancreas and ductal adenocarcinomas with scattered endocrine cells: characterization of the endocrine cells. Virchows Arch. 442, 258-265.

O'Toole, D., Saveanu, A., Couvelard, A., Gunz, G., Enjalbert, A., Jaquet, P., Ruszniewski, P., Barlier, A., 2006. The analysis of quantitative expression of somatostatin and dopamine receptors in gastro-enteropancreatic tumours opens new therapeutic strategies. Eur. J. Endocrinol. 155, 849-857.

Pacini, F., Basolo, F., Elisei, R., Fugazzola, L., Cola, A., Pinchera, A., 1991. Medullary thyroid cancer. An immunohistochemical and humoral study using six separate antigens. Am. J. Clin. Pathol. 95, 300-308.

Papotti, M., Bongiovanni, M., Volante, M., Allia, E., Landolfi, S., Helboe, L., Schindler, M., Cole, S.L., Bussolati, G., 2002. Expression of somatostatin receptor types 1-5 in 81 cases of gastrointestinal and pancreatic endocrine tumours. A correlative immunohistochemical and reverse-transcriptase polymerase chain reaction analysis. Virchows Arch. 440, 461-475.

Papotti, M., Cassoni, P., Volante, M., Deghenghi, R., Muccioli, G., Ghigo, E., 2001c. Ghrelin-producing endocrine tumours of the stomach and intestine. J. Clin. Endocrinol. Metab. 86, 5052-5059.

Papotti, M., Croce, S., Bello, M., Bongiovanni, M., Allia, E., Schindler, M., Bussolati, G., 2001a Expression of somatostatin receptor types 2, 3 and 5 in biopsies and surgical specimens of human lung tumours. Correlation with preoperative octreotide scintigraphy. Virchows Arch. 439, 787-797.

Papotti, M., Croce, S., Macri, L., Funaro, A., Pecchioni, C., Schindler, M., Bussolati, G., 2000. Correlative immunohistochemical and reverse transcriptase polymerase chain reaction analysis of somatostatin receptor type 2 in neuroendocrine tumours of the lung. Diagn. Mol. Pathol. 9, 47-57.

Papotti, M., Kumar, U., Volante, M., Pecchioni, C., Patel, Y.C., 2001b. Immunohistochemical detection of somatostatin receptor types 1-5 in medullary carcinoma of the thyroid. Clin. Endocrinol. (Oxf). 54, 641649.

Papotti, M., Macri, L., Bussolati, G., Reubi, J.C., 1989. Correlative study on neuro-endocrine differentiation and presence of somatostatin receptors in breast carcinomas. Int. J. Cancer. 43, 365-369.

Papotti, M., Tarabra, E., Allia, E., Bozzalla Cassione, F., Broglio, F., Deghenghi, R., Ghigo, E., Muccioli, G., 2003. Presence of cortistatin in the human pancreas. J. Endocrinol. Invest. 26, RC15-RC18.

Patel, Y.C., 1997. Molecular pharmacology of somatostatin receptor subtypes. J. Endocrinol. Invest. 20, 348-367.

Patel, Y.C., 1999. Somatostatin and its receptor family. Front. Neuroendocrinol. 20, 157-198.

Patel, Y.C., Greenwood, M.T., Panetta, R., Demchyshyn, L., Niznik, H., Srikant, C.B., 1995. The somatostatin receptor family. Life Sci. 57, 1249-1265.

Pfeiffer, M., Koch, T., Schroder, H., Klutzny, M., Kirscht, S., Kreienkamp, H.J., Hollt, V., Schulz, S., 2001. Homo- and heterodimerization of somatostatin receptor subtypes. Inactivation of sst(3) receptor function by heterodimerization with sst(2A). J. Biol. Chem. 2767, 14027-14036.

Pilichowska, M., Kimura, N., Schindler, M., Kobari, M., 2001. Somatostatin type 2A receptor immunoreactivity in human pancreatic adenocarcinomas. Endocr. Pathol. 12, 147-155.

Plonowski, A., Schally, A.V., Nagy, A., Sun, B., Szepeshazi, K., 1999. Inhibition of PC-3 human androgen-independent prostate cancer and its metastases by cytotoxic somatostatin analogue AN-238. Cancer Res. 59, 1947-1953. 
Qiu, C.Z., Wang, C., Huang, Z.X., Zhu, S.Z., Wu, Y.Y., Qiu, J.L., 2006. Relationship between somatostatin receptor subtype expression and clinicopathology, Ki-67, Bcl-2 and p53 in colorectal cancer. World J. Gastroenterol. 12, 2011-2015.

Raynor, K., Lucki, I., Reisine, T., 1993a. Somatostatin receptors in the nucleus accumbens selectively mediate the stimulatory effect of somatostatin on locomotor activity in rats. J. Pharmacol. Exp. Ther. 265, $67-73$.

Raynor, K., Murphy, W.A., Coy, D.H., Taylor, J.E., Moreau, J.P., Yasuda, K., Bell, G.I., Reisine, T., 1993b. Cloned somatostatin receptors: identification of subtype-selective peptides and demonstration of high affinity binding of linear peptides. Mol. Pharmacol. 43, 838-844.

Raynor, K., Reisine, T., 1992. Somatostatin receptors. Crit. Rev. Neurobiol. 6, 273-289.

Reichlin, S., 1998. Neuroendocrinology. In: Wilson, J.D. (ed.), Williams textbook of endocrinology, 9th ed. WB Saunders, Philadelphia, pp. 165-248.

Reisine, T., Bell, G.I., 1995. Molecular biology of somatostatin receptors. Endocr. Rev. 16, 427-442.

Reisinger, I., Bohuslavitzki, K.H., Brenner, W., Braune, S., Dittrich, I., Geide, A., Kettner, B., Otto, H.J., Schmidt, S., Munz, D.L., 1998. Somatostatin receptor scintigraphy in small-cell lung cancer: results of a multicenter study. J. Nucl. Med. 39, 224-227.

Reubi, C., Gugger, M., Waser, B., 2002. Co-expressed peptide receptors in breast cancer as a molecular basis for in vivo multireceptor tumour targeting. Eur. J. Nucl. Med. Mol. Imaging. 29, 855-862.

Reubi, J.C., 2004. Somatostatin and other Peptide receptors as tools for tumour diagnosis and treatment. Neuroendocrinology. 80(S1), 51-56.

Reubi, J.C., Chayvialle, J.A., Franc, B., Cohen, R., Calmettes, C., Modigliani, E., 1991. Somatostatin receptors and somatostatin content in medullary thyroid carcinomas. Lab. Invest. 64, 567-573.

Reubi, J.C., Kappeler, A., Waser, B., Laissue, J., Hipkin, R.W., Schonbrunn, A., 1998. Immunohistochemical localization of somatostatin receptors sst2A in human tumours. Am. J. Pathol. 153, 233-245.

Reubi, J.C., Krenning, E., Lamberts, S.W., Kvols, L., 1992b. In vitro detection of somatostatin receptors in human tumours. Metabolism. 41, 104-110.

Reubi, J.C., Laissue, J., Krenning, E., Lamberts, S.W., 1992a. Somatostatin receptors in human cancer: incidence, characteristics, functional correlates and clinical implications. J. Steroid. Biochem. Mol. Biol. 43, 27-35.

Reubi, J.C., Laissue, J., Waser, B., Horisberger, U., Schaer, J.C., 1994a. Expression of somatostatin receptors in normal, inflamed, and neoplastic human gastrointestinal tissues. Ann. N. Y. Acad. Sci. 733, 122137.

Reubi, J.C., Lang, W., Maurer, R., Koper, J.W., Lamberts, S.W., 1987. Distribution and biochemical characterization of somatostatin receptors in tumours of the human central nervous system. Cancer Res. 47, 5758-5764.

Reubi, J.C., Macke, H.R., Krenning, E.P., 2005. Candidates for peptide receptor radiotherapy today and in the future. J. Nucl. Med. 46(S1), 67S-75S.

Reubi, J.C., Schaer, J.C., Laissue, J.A., Waser, B., 1996. Somatostatin receptors and their subtypes in human tumours and in peritumoural vessels. Metabolism. 45, 39-41.

Reubi, J.C., Schaer, J.C., Markwalder, R., Waser, B., Horisberger, U., Laissue, J., 1997. Distribution of somatostatin receptors in normal and neoplastic human tissues: recent advances and potential relevance. Yale J. Biol. Med. 70, 471-479.

Reubi, J.C., Schaer, J.C., Waser, B., Mengod, G., 1994b. Expression and localization of somatostatin receptor sst1, sst2, and sst3 messenger RNAs in primary human tumours using in situ hybridization. Cancer Res. 54, 3455-3459.

Reubi, J.C., Schaer, J.C., Waser, B., Wenger, S., Heppeler, A., Schmitt, J.S., Macke, H.R., 2000a. Affinity profiles for human somatostatin receptor subtypes sst1-sst5 of somatostatin radiotracers selected for scintigraphic and radiotherapeutic use. Eur. J. Nucl. Med. 27, 273-282.

Reubi, J.C., Waser, B., Liu, Q., Laissue, J.A., Schonbrunn, A., 2000b. Subcellular distribution of somatostatin sst2A receptors in human tumours of the nervous and neuroendocrine systems: membranous versus intracellular location. J. Clin. Endocrinol. Metab. 85, 3882-3891.

Reubi, J.C., Waser, B., Schaer, J.C., Markwalder, R., 1995. Somatostatin receptors in human prostate and prostate cancer. J. Clin. Endocrinol. Metab. 80, 2806-2814.

Robas, N., Mead, E., Fidock, M., 2003. MrgX2 is a high potency cortistatin receptor expressed in dorsal root ganglion. J. Biol. Chem. 278, 44400-44404. 
Rocheville, M., Lange, D.C., Kumar, U., Sasi, R., Patel, R.C., Patel, Y.C., 2000. Subtypes of the somatostatin receptor assemble as functional homo- and heterodimers. J. Biol. Chem. 275, 7862-7869.

Rubinfeld, H., Hadani, M., Barkai, G., Taylor, J.E., Culler, M.D., Shimon, I., 2006. Cortistatin Inhibits Growth Hormone Release from Human Fetal and Adenoma Pituitary Cells and Prolactin Secretion from Cultured Prolactinomas. J. Clin. Endocrinol. Metab. 91, 2257-2263.

Saveanu, A., Gunz, G., Guillen, S., Dufour, H., Culler, M.D., Jaquet, P., 2006. Somatostatin and dopamine-somatostatin multiple ligands directed towards somatostatin and dopamine receptors in pituitary adenomas. Neuroendocrinology. 83, 258-263.

Schonbrunn, A., Tashjian, H. Jr., 1978. Characterization of functional receptors for somatostatin in rat pituitary cells in culture. J. Biol. Chem. 253, 6473-6483.

Sestini, R., Orlando, C., Peri, A., Tricarico, C., Pazzagli, M., Serio, M., Pagani, A., Bussolati, G., Granchi, S., Maggi, M., 1996. Quantitation of somatostatin receptor type 2 gene expression in neuroblastoma cell lines and primary tumours using competitive reverse transcription-polymerase chain reaction. Clin. Cancer Res. 2, 1757-1765.

Sibilia, V., Muccioli, G., Deghenghi, R., Pagani, F., De Luca, V., Rapetti, D., Locatelli, V., Netti, C. 2006. Evidence for a role of the GHS-R1a receptors in ghrelin inhibition of gastric acid secretion in the rat. J. Neuroendocrinol. 18,122-128.

Siehler, S., Seuwen, K., Hoyer, D., 1998. $\left.{ }^{125} \mathrm{I}\right] \mathrm{Tyr}^{10}$-cortistatin-14 labels all five somatostatin receptors. Naunyn Schmiedebergs Arch. Pharmacol. 357, 483-489.

Smith, M.C., Liu, J., Chen, T., Schran, H., Yeh, C.M., Jamar, F., Valkema, R., Bakker, W., Kvols, L., Krenning, E., Pauwels, S., 2000. OctreoTher: ongoing early clinical development of a somatostatin-receptortargeted radionuclide antineoplastic therapy. Digestion. 62, 69-72.

Soga, J., Yakuwa, Y., 1999. Somatostatinoma/inhibitory syndrome: a statistical evaluation of 173 reported cases as compared to other pancreatic endocrinomas. J. Exp. Clin. Cancer Res. 18, 13-22.

Spier, A.D., de Lecea, L., 2000. Cortistatin: a member of the somatostatin neuropeptide family with distinct physiological functions. Brain Res. Brain Res. Rev. 33, 228-241.

Spier, A.D., Fabre, V., de Lecea, L., 2005. Cortistatin radioligand binding in wild-type and somatostatin receptor-deficient mouse brain. Regul. Pept.124, 179-186.

Srikant, C.B., Heisler, S., 1985. Relationship between receptor binding and biopotency of somatostatin14 and somatostatin-28 in mouse pituitary tumour cells. Endocrinology. 117, 271-278.

Taboada, G.F., Luque, R.M., Bastos, W., Guimaraes, R.F., Marcondes, J.B., Chimelli, L.M., Fontes, R., Mata, P.J., Filho, P.N., Carvalho, D.P., Kineman, R.D., Gadelha, M.R., 2007. Quantitative analysis of somatostatin receptor subtype (sst1-5) gene expression levels in somatotropinomas and non-functioning pituitary adenomas. Eur. J. Endocrinol. 156, 65-74.

Tamiolakis, D., Simopoulos, C., Venizelos, J., Lambropoulou, M., Nikolaidou, S., Tsikouras, P., Koutsougeras, G., Alexiadis, G., Menegaki, M., Papadopoulos, N., 2005. Distribution of somatostatin in pancreatic ductal adenocarcinoma remodels the normal pattern of the protein during foetal pancreatic development: an immunohistochemical analysis. Clin. Exp. Med. 5, 106-111.

Ueberberg, B., Tourne, H., Redman, A., Walz, M.K., Schmid, K.W., Mann, K., 2005. Petersenn S.Differential expression of the human somatostatin receptor subtypes sst1 to sst5 in various adrenal tumours and normal adrenal gland. Horm. Metab. Res. 37, 722-728.

Vainas, I.G., 2001. Octreotide in the management of hormone-refractory prostate cancer. Chemotherapy. 47, 109-126.

Vernejoul, F., Faure, P., Benali, N., Calise, D., Tiraby, G., Pradayrol, L., Susini, C., Buscail, L., 2002. Antitumour effect of in vivo somatostatin receptor subtype 2 gene transfer in primary and metastatic pancreatic cancer models. Cancer Res. 6, 6124-6131.

Vikic-Topic, S., Raisch, K.P., Kvols, L.K., Vuk-Pavlovic, S., 1995. Expression of somatostatin receptor subtypes in breast carcinoma, carcinoid tumour, and renal cell carcinoma. J. Clin. Endocrinol. Metab. 80, 2974-2979.

Volante, M., Allia, E., Gugliotta, P., Funaro, A., Broglio, F., Deghenghi, R., Muccioli, G., Ghigo, E., Papotti, M., 2002. Expression of ghrelin and of the GH secretagogue receptor by pancreatic islet cells and related endocrine tumours. J. Clin. Endocrinol. Metab. 87, 1300-1308.

Volante, M., Bozzalla-Cassione, F., Papotti, M., 2004. Somatostatin receptors and their interest in diagnostic pathology. Endocr. Pathol. 15, 275-291.

Wang, C.H., Tang, C.W., Liu, C.L., Tang, L.P., 2003. Inhibitory effect of octreotide on gastric cancer growth via MAPK pathway. World J. Gastroenterol. 9, 1904-1908. 
Weber, C.J., O'Dorisio, T.M., Howe, B., D'Agati, V., Ward, L., Russell, J., Feind, C.R., 1991. Vasoactive intestinal polypeptide-, neurotensin-, substance P-, gastrin-releasingpeptide-, calcitonin-, calcitonin gene related peptide-, and somatostatin-like immunoreactivities in human parathyroid glands. Surgery 110, 1078-1085.

Weir, G.C., Bonner-Weir, S., 1985. Pancreatic somatostatin. Adv. Exp. Med. Biol. 188, 403-423.

Zatelli, M.C., Piccin, D., Vignali, C., Tagliati, F., Ambrosio, M.R., Bondanelli, M., Cimino, V., Bianchi, A., Schmid, H.A., Scanarini, M., Pontecorvi, A., De Marinis, L., Maira, G., degli Uberti, E.C., 2007. Pasireotide, a multiple somatostatin receptor subtypes ligand, reduces cell viability in non-functioning pituitary adenomas by inhibiting vascular endothelial growth factor secretion. Endocr. Relat. Cancer. 14, 91102.

Zatelli, M.C., Piccin, D., Tagliati, F., Bottoni, A., Luchin, A., Vignali, C., Margutti, A., Bondanelli, M., Pansini, G.C., Pelizzo, M.R., Culler, M.D., Degli Uberti, E.C., 2006. Selective activation of somatostatin receptor subtypes differentially modulates secretion and viability in human medullary thyroid carcinoma primary cultures: potential clinical perspectives. J. Clin. Endocrinol. Metab. 91, 2218-2224.

Zhang, C.Y., Yokogoshi, Y., Yoshimoto, K., Fujinaka, Y., Matsumoto, K., Saito, S., 1995. Point mutation of the somatostatin receptor 2 gene in the human small cell lung cancer cell line COR-L103. Biochem. Biophys. Res. Commun. 210, 805-815.

Zhao, B., Zhao, H., Zhao, N., Zhu, X.G., 2002. Cholangiocarcinoma cells express somatostatin receptor subtype 2 and respond to octreotide treatment. J. Hepatobiliary. Pancreat. Surg. 9, 497-502. 


\section{TABLE 1: SS and CST in human tumours: known ligand-receptor interactions}

$\underline{\text { Ligands }}$

SS

CST

[AdrenoMedullin]

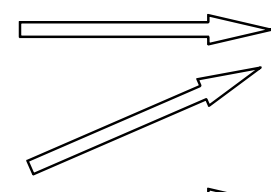

[Ghrelin] $\underline{\text { Receptors }}$

sst $1-5$

$\operatorname{MrgX-2}$

Abbreviations: SS: somatostatin; CST: cortistatin; sst: somatostatin receptors;

GHSR: growth hormone secretagogue receptor; GRN-R: ghrelin receptor

\section{FIGURE LEGENDS}

Fig. 1 - Functioning somatostatinoma of the pancreas. The typical organoid and trabecular structure of well differentiated neuroendocrine tumours is observed in conventional Hematoxylin \& Eosin stained sections (a). In serial sections, several somatostatin (b) and cortistatin (c, arrows) immunoreactive cells are recognized. The typical elongated shape of many neuroendocrine cells, with occasional cytoplasmic extensions, is better highlighted in the insets $(b, c)$. The tumour also expresses somatostatin receptors type 2 (d). A membrane localisation of the receptor is observed with weak cytoplasmic staining in some cells, possibly indicating receptor internalisation mediated by the presence of both endogenous ligands in the same tumour. [b-d: Immunoperoxidase, nuclei counterstained with haemalum; a-b-c: 200x; insets and d: 400x]

Fig. 2 - Schematic comparison of cortistatin and somatostatin expression in human neuroendocrine tumours. Although most tumours were found to produce both hormones, notable exceptions exist, including parathyroid and hindgut tumours. 

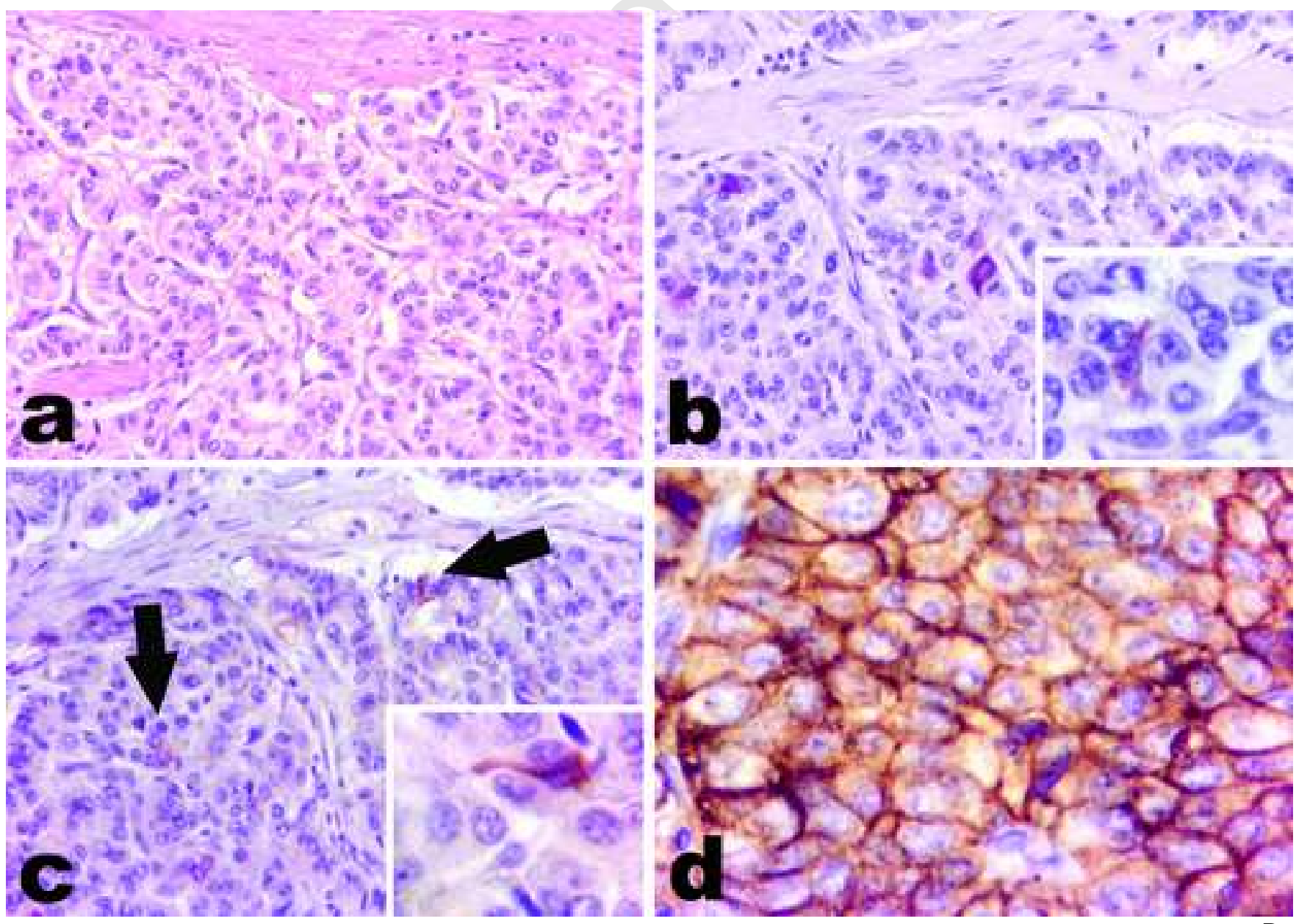


\section{CORTISTATIN}

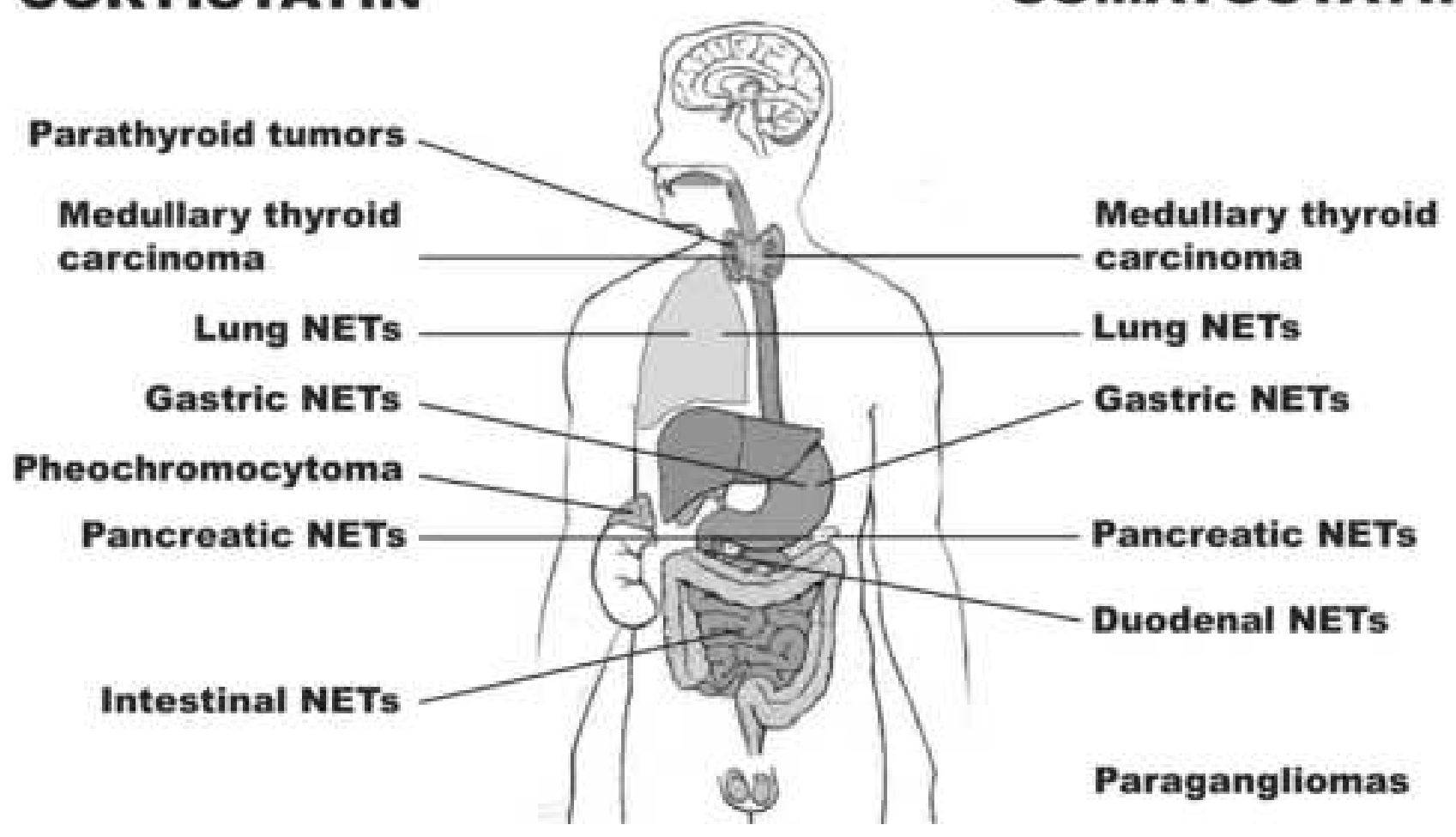

SOMATOSTATIN 